\title{
Pericardial effusion post antero-hernia repair using mesh and tacker: case report
}

\author{
Anaëlle Chermat ${ }^{1}$ Jean Marc Baste ${ }^{2}$ \\ ${ }^{1}$ Department of Thoracic and Cardiovascular Surgery, CHU Dupuytren 2, Limoges, France; ${ }^{2}$ Department of Thoracic and Cardiovascular Surgery, \\ CHU de Rouen, Rouen, France \\ Correspondence to: Anaëlle Chermat. Service de Chirurgie Thoracique et Cardiovasculaire, CHU Dupuytren 2, 16 rue Bernard Descottes, 87000 \\ Limoges, France. Email: anaelle.chermat@orange.fr.
}

\begin{abstract}
We present a case report of a 66-year-old female who underwent antero-hiatal-hernia repair by laparoscopy. After dissection to make a direct suture, too much tension on tissues lead us to use a mesh fixed by tacker. In the follow-up our patient developed thoracic pain. We diagnose a pericardial effusion. Different other manner than tacker should be used to avoid this kind of complication.
\end{abstract}

Keywords: Pericardial effusion; tacker; hiatal hernia; case report

Received: 09 November 2019; Accepted: 03 December 2019; Published: 05 July 2020.

doi: 10.21037 /jovs.2019.12.06

View this article at: http://dx.doi.org/10.21037/jovs.2019.12.06

\section{Introduction}

Morgagni-Larrey hernias are "rare congenital diaphragmatic hernias" that present later in life (1). They are frequently associated with elusive clinical and radiological findings. Occurrence on the right side is common, left side is few, and bilateral is rare.

We report here on a case of antero-hernia repair by laparoscopy using mesh and tacker. The follow-up and the complication leading to change our technique.

\section{Case presentation}

All procedures performed in this study were in accordance with the Helsinki Declaration (as revised in 2013). Written informed consent was obtained from the patient for publication of this manuscript and any accompanying images.

We present the case of a 66-year-old female who was diagnose an antero-hiatal hernia on a computed tomography (CT) scan, perform because of abdominal pain. A surgical treatment has been decided.

Under general anesthesia. The patient lying down on dorsal decubitus.

Three ports were used, above the umbilicus. The first one, size 11 , just above the umbilicus. The two other, size 5 and 10 , were placed under the ribs.

At the first inspection, a large antero-hernia, more than $5 \mathrm{~cm}$, was observed.

A reduction of the hernia content in the abdominal cavity was performed.

Then the surgeon dissected and liberated the hernial orifice. The aim is to make the orifice flexible enough and freely mobile, to permit a direct closure by suture.

Unfortunately, the tissue mobilisation was limited. And direct suturing seems to be impossible.

Primary closure was attempted, but abandoned due to the wide hernia orifice and so, too much tension on tissues.

The decision was taken to use a mesh, to cover the defect. PARIETX mesh has been used. It seems to be safer, to avoid tear off the tissue. The mesh was fixed, all around the diaphragm, by helical tackers (ABSORBATACK).

The patient has been discharged the day after the surgery without any pain. After a normal chest X-ray. Followup medical consultation was organized 3 weeks after the surgery.

During the follow-up medical consultation, the patient complained pain. It has been given anti-inflammatory drug for 1 week. Because of suspicion of recurrence, a medical prescription for a CT scan has been given to the patient. 


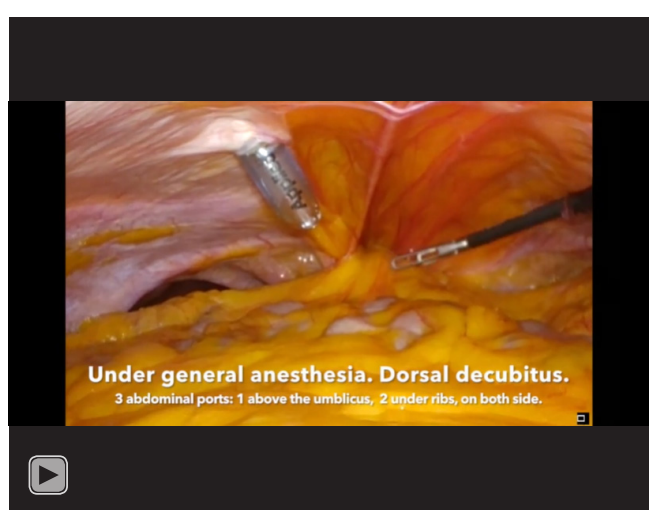

Video 1 Surgical technique video of antero-hernia repair by laparoscopy (2).

After the CT scan, she was directly hospitalized at the cardiology intensive care unit. Pericardial effusion has been discovered, 1 month after the hernia surgery. Because of no impact on the heart, and a well tolerance by the patient, it has been decided that no intervention on the pericardial effusion. Even not a pericardial drainage.

Later, the patient developed a fever. She has been hospitalized at the infectious department. An intensive infectious research has been done. All the samples were negative. A new CT scan were performed. No abscess was found around the mesh. And we noticed, a pericardial effusion regression.

Three months after the antero-hernia surgery, the control CT scan did not show any residual pericardial effusion (Video 1).

\section{Discussion}

Our patient developed a reactional pericardial effusion after the hernia reduction surgery, probably because of the use of helical tack to attach the mesh.

Several complications have been reported about using mesh for inguinal hernia repair: pain, seroma, recurrence, mesh infection, erosion (3). Only few cases were reported with complications after hiatal hernia repair.

More dangerous complication can occur because of the fixation system. Indeed, this Area is very close to the heart. Only the tendinous, thin central part of the diaphragm separate it from the heart (4).

The inappropriate fixation of mesh to the central tendon of the diaphragm can cause inadvertent cardiac injury resulting in a fatal tamponade (3). In Constantine
T. Frantzides and all review, they found six cases of cardiac injury after hiatal hernia repair and one case after the repair of a ventral hernia. Three were fatal. Different fixation systems were used: helical tacker, direct suture, straight stapler.

A Danish article report about a 79-year-old Woman who died 9 hours after her surgery. She underwent a laparoscopic procedure with mesh implantation. Tackers were used to secure the mesh to the diaphragm. Autopsy showed perforation of the pericardium and the right coronary artery by a tacker (5).

The position of this fixated material is very important. A correct view is not always possible, especially on both side of the diaphragm.

So a no use-of-tacker policy should be considered in this area. The endpoint of tacker can cause severe injury to the heart. Clinical symptom as persistent hypotension must alert the team after using tacker or other fixated material around the heart.

According to a recent systematic review of the literature, graft fixation, around the ante-hiatal diaphragmatic dome must be abandoned. If mesh has to be used, a meticulous stitching must be preferred instead of fixators (6).

But still, using needle in this area is dangerous. A new option for mesh fixation, especially in this area, could be by using fibrin glue. An in vitro study by Hamilton et al. concluded that the fixation done by glue is stronger than tacks in the immediate post-procedure period (7). This fixating material could avoid chronic pain given by tacker, and dangerous injuries. In a comparative study between fibrin glue and tacker for mesh fixation, using fibrin glue has same quality result than tacker, but less side effect as hematoma or seroma (8)

\section{Conclusions}

The use of tacker should be forbidden in cardiac and noble great vessels area.

\section{Acknowledgments}

Funding: None.

\section{Footnote}

Conflicts of Interest: Both authors have completed the ICMJE uniform disclosure form (available at https://jovs. amegroups.com/article/view/10.21037/jovs.2019.12.06/ 
coif). JMB serves as an unpaid editorial board member of Fournal of Visualized Surgery from December 2017 to November 2019. The other author has no conflicts of interest to declare.

Ethical Statement: The authors are accountable for all aspects of the work in ensuring that questions related to the accuracy or integrity of any part of the work are appropriately investigated and resolved. All procedures performed in this study were in accordance with the Helsinki Declaration (as revised in 2013). Written informed consent was obtained from the patient for publication of this manuscript and any accompanying images. A copy of the written consent is available for review by the Editor-inChief of this journal.

Open Access Statement: This is an Open Access article distributed in accordance with the Creative Commons Attribution-NonCommercial-NoDerivs 4.0 International License (CC BY-NC-ND 4.0), which permits the noncommercial replication and distribution of the article with the strict proviso that no changes or edits are made and the original work is properly cited (including links to both the formal publication through the relevant DOI and the license). See: https://creativecommons.org/licenses/by-nc-nd/4.0/.

doi: 10.21037 /jovs.2019.12.06

Cite this article as: Chermat A, Baste JM. Pericardial effusion post antero-hernia repair using mesh and tacker: case report. J Vis Surg 2020;6:30.

\section{References}

1. Abraham V, Myla Y, Verghese S, et al. Morgagni-larrey hernia- a review of 20 cases. Indian J Surg 2012;74:391-5.

2. Chermat A, Baste JM. Surgical technique video of anterohernia repair by laparoscopy. Asvide 2020;7:072. Available online: http://www.asvide.com/watch/33111

3. Frantzides CT, Welle SN. Cardiac tamponade as a lifethreatening complication in hernia repair. Surgery 2012;152:133-5.

4. Bains KNS, Lappin SL. Anatomy, Thorax, Diaphragm. StatPearls Publishing LLC, 2018.

5. Jørgensen JB, Lundbech PE, Rask P, et al. Cardiac tamponade after laparoscopic operation for a traumatic. Ugeskr Laeger 2014;176(25A).

6. Çalıkoğlu İ, Özgen G, Toydemir T, et al. Iatrogenic cardiac tamponade as a mortal complication of peri-hiatal surgery. Analysis of 30 published cases. Heliyon 2019;5:e01537.

7. Hamilton D, Tan J, Chandraratna H. Fibrin glue provides stronger mesh fixation than tacks: An in vivo study. Surg Rehabil 2018;2:1-3.

8. Chandra P, Phalgune D, Shah S. Comparison of the Clinical Outcome and Complications in Laparoscopic Hernia Repair of Inguinal Hernia With Mesh Fixation Using Fibrin Glue vs Tacker. Indian J Surg 2016;78:464-70. 